\title{
Effectiveness of laser irradiation in preventing enamel demineralization during orthodontic treatment: A systematic review
}

\section{Skuteczność promieniowania laserowego w zapobieganiu demineralizacji szkliwa podczas leczenia ortodontycznego - systematyczny przegląd piśmiennictwa}

\author{
Tuqa Rashad Raghis ${ }^{1, A-D, F}$, Ghiath Mahmoud ${ }^{1, B-F}$, Omar Hamadah',2, ,E,F \\ ${ }^{1}$ Department of Orthodontics, Faculty of Dental Medicine, University of Damascus, Syria \\ ${ }^{2}$ Higher Institute for Laser Research and Applications, University of Damascus, Syria \\ A - research concept and design; $B$ - collection and/or assembly of data; $C$ - data analysis and interpretation; \\ $D$ - writing the article; $E$ - critical revision of the article; $F$ - final approval of the article
}

\section{Address for correspondence \\ Omar Hamadah}

E-mail: omar.hamadah@gmail.com

\section{Funding sources}

None declared

Conflict of interest

None declared

\section{Acknowledgements}

The authors would like to kindly thank Dr. Michaela Goodson for her linguistic assistance.

Received on April 29, 2018 Reviewed on June 14, 2018 Accepted on June 27, 2018

\begin{abstract}
The objective of this study was to investigate the in vivo effectiveness of laser in the prevention of enamel demineralization during orthodontic treatment.

A search of electronic databases (PubMed, ScienceDirect, Google Scholar, Scopus, the Cochrane Central Register of Controlled Trials - CENTRAL, OpenGrey, and ProQuest Dissertations and Theses - PQDT Open from ProQuest) was carried out. In vivo studies, randomized and/or controlled clinical trials regarding the use of laser treatment to prevent enamel demineralization during orthodontic treatment were included. The risk of bias of the studies included was assessed independently by 2 authors according to Cochrane guidelines.

Eight articles were identified, comprising a total of 183 patients. Significant differences were observed in enamel demineralization between laser-irradiated and control groups for all laser types: argon laser, $\mathrm{CO}_{2}$ laser, neodymium-doped yttrium aluminum garnet (Nd:YAG) laser, and Optodan ${ }^{\circledR}$ laser, except for argon laser application for curing bracket adhesives, where no statistically significant differences were noted.

Laser irradiation may be effective in inhibiting demineralization during orthodontic treatment, but there is a need for further randomized, controlled clinical trials, utilizing different laser systems to determine real clinical efficacy of the technique.
\end{abstract}

Key words: prevention, laser, orthodontics, white spot lesions, demineralization

Słowa kluczowe: zapobieganie, laser, ortodoncja, białe plamy próchnicowe, demineralizacja

D0I

10.17219/dmp/92636

Copyright

○ 2018 by Wroclaw Medical University

and Polish Dental Society

This is an article distributed under the terms of the

Creative Commons Attribution Non-Commercial License

(http://creativecommons.org/licenses/by-nc-nd/4.0/) 


\section{Introduction}

Enamel demineralization or white spot lesion (WSL) development during orthodontic treatment with fixed appliances is a common clinical problem in modern orthodontic practice. ${ }^{1}$ Fixed attachments may encourage prolonged plaque accumulation, particularly in patients with poor oral hygiene, compliancy or disability. ${ }^{2}$ In addition, a prolonged period of fixed orthodontic treatment increases the risk of WSL formation. ${ }^{3}$

The prevalence of WSLs in patients undergoing orthodontic treatment is about $68.4 \%$, so professional preventive procedures are recommended for fixed orthodontic treatment patients. ${ }^{3}$ The responsibility of the orthodontist is to minimize decalcification through education and motivation of the patient to maintain good oral hygiene. ${ }^{4}$ Topical fluoride (high-fluoride toothpaste, fluoride mouthwashes, gels and varnishes) is effective in caries prevention and management of WSLs during and after orthodontic treatment. ${ }^{5}$

There is evidence in the literature that laser irradiation modifies the enamel structure, making it more resistant to acid dissolution, ${ }^{6}$ so laser application may serve as a preventive measure for WSL formation for orthodontic patients without relying on patient compliancy.

Several types of laser beams have been used to increase enamel resistance to decalcification during orthodontic treatment. These include $\mathrm{CO}_{2}$, neodymium-doped yttrium aluminum garnet (Nd:YAG), erbium-doped yttrium aluminum garnet (Er:YAG), erbium, chromium: yattrium-scandium-gallium-garnet (Er, Cr:YSGG), diode, and argon lasers. ${ }^{7,8}$
The effectiveness of different lasers in decreasing the susceptibility of the enamel surface to caries have been investigated mostly by in vitro studies and a handful of in vivo studies, ${ }^{8,9}$ but the clinical evidence about laser effectiveness is still unclear. There is only 1 published systematic review investigating the effect of lasers in preventing demineralization during orthodontic treatment; however, this study did not involve all types of laser beams that could be applied for this purpose. ${ }^{10}$ Equally, there are no reports about the effective and safe laser parameters for clinical use in managing WSL formation.

The aim of this systematic review is to investigate the in vivo effectiveness of different types of laser in preventing enamel demineralization during orthodontic treatment. A secondary aim is to evaluate, using published reports, the effective and safe laser settings that can be used to manage demineralization during orthodontic treatment.

\section{Material and methods}

\section{Protocol and registration}

This systematic review was conducted following the Preferred Reporting Items for Systematic Reviews and Meta-Analyses (PRISMA) guidelines. ${ }^{11}$

Review questions:

1. Does laser irradiation significantly increase enamel resistance to demineralization during orthodontic treatment?

2. What are the most effective and safest lasers for the prevention of demineralization related to orthodontic treatment?

Table 1. Review questions - PICO study design

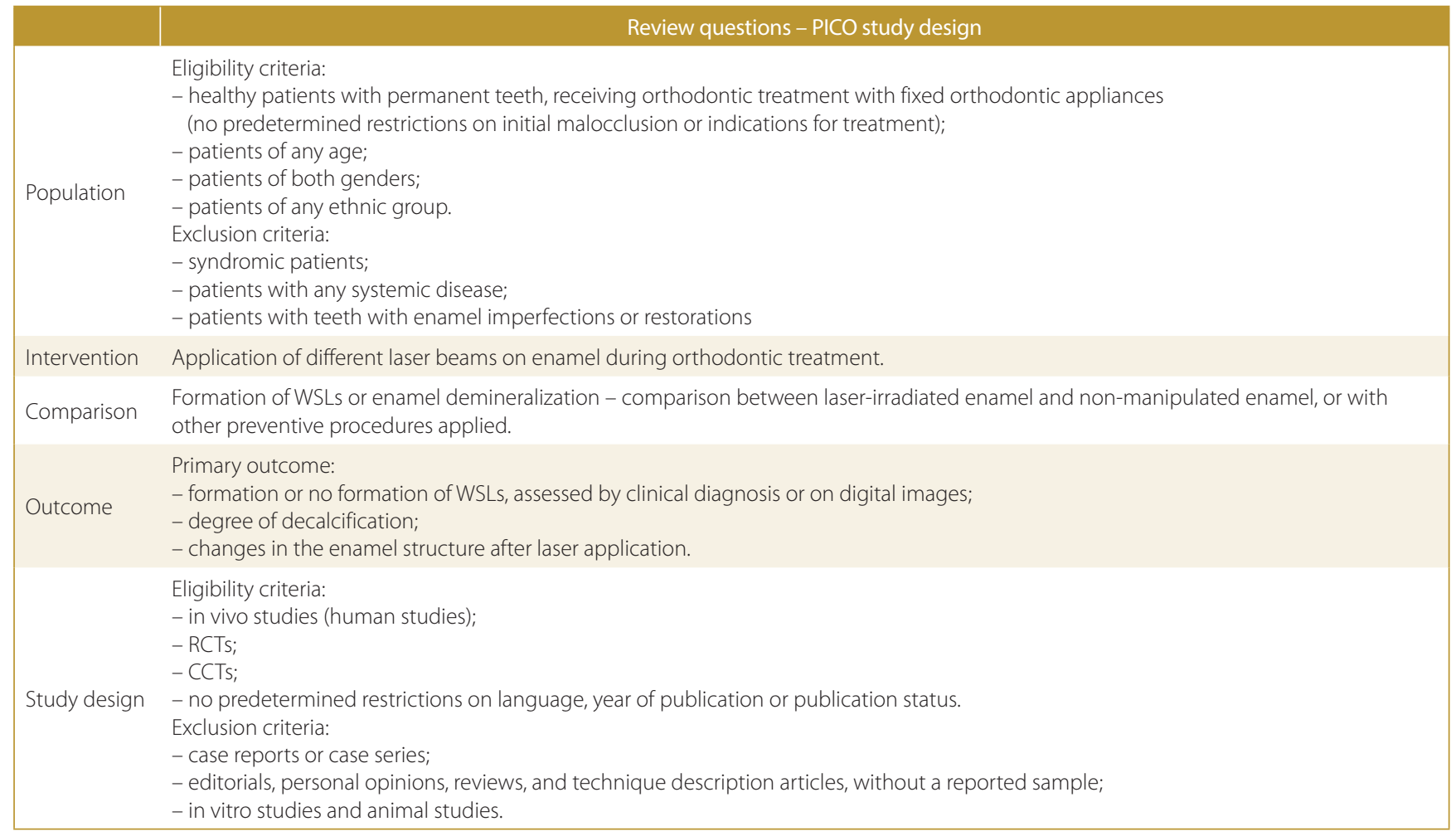

Review questions - PICO study design

PICO - population, intervention, comparison, and outcome study design; WSL - white spot lesion; RCT - randomized controlled trial; CCT - controlled clinical trial. 
These review questions were developed according to the population, intervention, comparison, and outcome (PICO) study design (Table 1).

\section{Types of publications}

This review included all publications, regardless of language, about the clinical application of different laser types to prevent WSLs or enamel demineralization during fixed orthodontic treatment. Personal opinions, editorials, literature reviews, and abstracts were excluded.

Eligibility criteria of the population were:

- healthy patients with permanent teeth, receiving orthodontic treatment with fixed orthodontic appliances;

- patients of any age;

- patients of both genders;

- patients of any ethnic groups.

Exclusion criteria of the population were:

- syndromic patients;

- patients with any systemic disease;

- patients with teeth with enamel imperfections or restorations.

\section{Information sources}

The search strategy incorporated searching electronic databases, supplemented by hand searching. The electronic search was performed in PubMed (National Library of Medicine - NLM, National Center for Biotechnology Information - NCBI), ScienceDirect, Google Scholar, Scopus, the Cochrane Central Register of Controlled Trials (CENTRAL), OpenGrey (to identify the grey literature), and ProQuest Dissertations and Theses (PQDT Open) from ProQuest (to identify dissertations and theses). The references of each relevant study were screened to discover additional relevant publications and to improve the sensitivity of the search. ClinicalTrials.gov and the World Health Organization International Clinical Trials Registry Platform Search Portal (ICTRP) were also screened to evaluate any unpublished studies or current accomplished research work.

Hand searching was carried out in the following journals: "American Journal of Orthodontics and Dentofacial Orthopedics"; "Australasian Orthodontic Journal"; "Caries Research"; "European Journal of Orthodontics"; "Journal of Biomedical Optics"; "Lasers in Medical Science"; "Lasers in Surgery and Medicine"; "Laser Therapy"; "Orthodontics and Craniofacial Research"; "Photomedicine and Laser Surgery"; "Seminars in Orthodontics"; "Angle Orthodontist"; "Journal of Orthodontics"; and "Korean Journal of Orthodontics".

\section{Search}

PubMed, Scopus, ScienceDirect, Google Scholar, and Cochrane databases were explored through advanced searches. The search was conducted in June 2017, using the following keywords: (laser therapy) OR (laser irradiation) OR (laser application) AND (enamel caries prevention) OR (enamel resistance) OR (enamel decalcification) OR (enamel demineralization) OR (white spot lesions WSLs) OR (enamel dissolution) OR (enamel microhardness) AND (orthodontics) OR (orthodontic treatment) OR (orthodontic brackets) OR (fixed appliances). The full electronic search strategy is presented in Supplementary Material 1.

\section{Study selection}

The obtained articles were independently subjected to clear inclusion and exclusion criteria by 2 authors (TRR and GM).

Inclusion criteria for the studies were:

- in vivo studies (human studies);

- randomized controlled trials (RCTs);

- controlled clinical trials (CCTs).

Exclusion criteria for the studies were:

- case reports or case series;

- editorials, personal opinions, reviews, and technique description articles, without a reported sample;

- in vitro studies and animal studies.

\section{Sequential search strategy}

Firstly, all article titles were screened and the irrelevant articles, reviews, case reports, and in vitro studies were excluded. Then, abstracts of the remaining articles were screened to eliminate studies based on data obtained from abstracts. Finally, the full text of the remaining articles was screened to confirm the acceptability of the articles depending on the inclusion and exclusion criteria.

The authors compared their decisions and resolved differences through discussion, consulting a third author $(\mathrm{OH})$ when consensus could not be reached. The $3^{\text {rd }}$ author was an experienced senior reviewer.

\section{Data extraction}

The data was extracted from the studies according to the aims of the systematic review by the same 2 authors (TRR and GM) independently and were arranged in the following fields: general information (name of author and year of publication); study characteristics (study design and treatment comparison); sample description (size, age and sex); laser application (type of laser beam, laser parameters and details of irradiation protocol); and outcomes (primary outcomes, methods of primary outcome measurement, and statistical significance of the reported differences between treated and control groups). 
Supplementary Material 1. Literature databases searched with a search strategy (last search on June 30, 2017)

\begin{tabular}{|c|c|c|c|c|c|c|}
\hline Database & Site & Search strategy & $\begin{array}{l}\text { Search } \\
\text { builder }\end{array}$ & Limits & Items & $\begin{array}{l}\text { Items } \\
\text { involved } \\
\text { after } \\
\text { excluding } \\
\text { irrelevant } \\
\text { articles }\end{array}$ \\
\hline PubMed & $\begin{array}{l}\text { http://www.ncbi.nlm.nih. } \\
\text { gov/pubmed/ }\end{array}$ & $\begin{array}{l}\text { (laser therapy) OR (laser irradiation) OR (laser application) } \\
\text { AND (enamel caries prevention) OR (enamel resistance) } \\
\text { OR (enamel decalcification) OR (enamel demineralization) } \\
\text { OR (white spot lesions WSLs) OR (enamel dissolution) OR } \\
\text { (enamel microhardness) AND (orthodontics) OR (orthodontic } \\
\text { treatment) OR (orthodontic brackets) OR (fixed appliances) }\end{array}$ & all fields & - & 42,045 & 106 \\
\hline $\begin{array}{l}\text { CENTRAL } \\
\text { (Cochrane } \\
\text { Library) }\end{array}$ & $\begin{array}{l}\text { http:// www.cochranelibrary. } \\
\text { com/ }\end{array}$ & $\begin{array}{l}\text { (laser therapy) OR (laser irradiation) OR (laser application) } \\
\text { AND (enamel caries prevention) OR (enamel resistance) } \\
\text { OR (enamel decalcification) OR (enamel demineralization) } \\
\text { OR (white spot lesions WSLs) OR (enamel dissolution) OR } \\
\text { (enamel microhardness) AND (orthodontics) OR (orthodontic } \\
\text { treatment) OR (orthodontic brackets) OR (fixed appliances) }\end{array}$ & $\begin{array}{c}\text { title, } \\
\text { abstract, } \\
\text { keywords }\end{array}$ & trials & 8,650 & 27 \\
\hline ScienceDirect & $\begin{array}{l}\text { https://www.sciencedirect. } \\
\text { com/ }\end{array}$ & $\begin{array}{l}\text { (laser therapy) OR (laser irradiation) OR (laser application) } \\
\text { AND (enamel caries prevention) OR (enamel resistance) } \\
\text { OR (enamel decalcification) OR (enamel demineralization) } \\
\text { OR (white spot lesions WSLs) OR (enamel dissolution) OR } \\
\text { (enamel microhardness) AND (orthodontics) OR (orthodontic } \\
\text { treatment) OR (orthodontic brackets) OR (fixed appliances) }\end{array}$ & $\begin{array}{c}\text { title, } \\
\text { abstract, } \\
\text { keywords }\end{array}$ & - & 7 & 6 \\
\hline $\begin{array}{l}\text { Google } \\
\text { Scholar }\end{array}$ & https://scholar.google.com/ & $\begin{array}{l}\text { (laser therapy) OR (laser irradiation) OR (laser application) } \\
\text { AND (enamel caries prevention) OR (enamel resistance) } \\
\text { OR (enamel decalcification) OR (enamel demineralization) } \\
\text { OR (white spot lesions WSLs) OR (enamel dissolution) OR } \\
\text { (enamel microhardness) AND (orthodontics) OR (orthodontic } \\
\text { treatment) OR (orthodontic brackets) OR (fixed appliances) }\end{array}$ & - & - & 1,520 & 53 \\
\hline Scopus & http://www.scopus.com/ & $\begin{array}{l}\text { (laser therapy) OR (laser irradiation) OR (laser application) } \\
\text { AND (enamel caries prevention) OR (enamel resistance) } \\
\text { OR (enamel decalcification) OR (enamel demineralization) } \\
\text { OR (white spot lesions WSLs) OR (enamel dissolution) OR } \\
\text { (enamel microhardness) AND (orthodontics) OR (orthodontic } \\
\text { treatment) OR (orthodontic brackets) OR (fixed appliances) }\end{array}$ & $\begin{array}{c}\text { title, } \\
\text { abstract, } \\
\text { keywords }\end{array}$ & - & 118 & 22 \\
\hline OpenGrey & http://www.opengrey.eu/ & $\begin{array}{l}\text { (laser therapy) OR (laser irradiation) OR (laser application) } \\
\text { AND (enamel caries prevention) OR (enamel resistance) } \\
\text { OR (enamel decalcification) OR (enamel demineralization) } \\
\text { OR (white spot lesions WSLs) OR (enamel dissolution) OR } \\
\text { (enamel microhardness) AND (orthodontics) OR (orthodontic } \\
\text { treatment) OR (orthodontic brackets) OR (fixed appliances) }\end{array}$ & - & orthodontics & 416 & 5 \\
\hline $\begin{array}{l}\text { PQDT } \\
\text { Open (from } \\
\text { ProQuest) }\end{array}$ & $\begin{array}{l}\text { http://pqdtopen.proquest. } \\
\text { com/ }\end{array}$ & $\begin{array}{l}\text { (laser therapy) OR (laser irradiation) OR (laser application) } \\
\text { AND (enamel caries prevention) OR (enamel resistance) } \\
\text { OR (enamel decalcification) OR (enamel demineralization) } \\
\text { OR (white spot lesions WSLs) OR (enamel dissolution) OR } \\
\text { (enamel microhardness) AND (orthodontics) OR (orthodontic } \\
\text { treatment) OR (orthodontic brackets) OR (fixed appliances) }\end{array}$ & - & - & 0 & 0 \\
\hline $\begin{array}{l}\text { ClinicalTrials. } \\
\text { gov }\end{array}$ & https://clinicaltrials.gov/ & $\begin{array}{l}\text { Condition or disease: (enamel caries prevention) OR } \\
\text { (enamel resistance) OR (enamel decalcification) OR (enamel } \\
\text { demineralization) OR (white spot lesions WSLs) OR (enamel } \\
\text { dissolution) OR (enamel microhardness) } \\
\text { Other terms: (laser therapy) OR (laser irradiation) OR (laser } \\
\text { application) AND (orthodontics) OR (orthodontic treatment) } \\
\text { OR (orthodontic brackets) OR (fixed appliances) }\end{array}$ & all & - & 8 & 1 \\
\hline WHO ICTRP & $\begin{array}{l}\text { http://apps.who.int/ } \\
\text { trialsearch/ }\end{array}$ & $\begin{array}{l}\text { (laser therapy) OR (laser irradiation) OR (laser application) } \\
\text { AND (enamel caries prevention) OR (enamel resistance) } \\
\text { OR (enamel decalcification) OR (enamel demineralization) } \\
\text { OR (white spot lesions WSLs) OR (enamel dissolution) OR } \\
\text { (enamel microhardness) AND (orthodontics) OR (orthodontic } \\
\text { treatment) OR (orthodontic brackets) OR (fixed appliances) }\end{array}$ & all & - & 776 & 2 \\
\hline Overall & & & & & 53,540 & $222^{*}$ \\
\hline
\end{tabular}

* There were 53,540 items identified from electronic databases. 473 items were added through hand searching and references screening. After excluding irrelevant articles, there were 222 items involved from electronic search and 150 items from hand searching and references screening. Then, after filtering for duplication, there were 304 items left (155 items from electronic databases and 149 items from hand searching and references screening). 


\section{Assessment of methodological quality}

The risk of bias of the included trials was also assessed independently by the same 2 authors (TRR and GM), using the recommended approach for assessing the risk of bias in studies included in Cochrane reviews. ${ }^{12}$ The studies were evaluated in the following fields as low, high or unclear risk of bias: sequence generation (selection bias); allocation concealment (selection bias); blinding of participants and personnel (performance bias); blinding of outcome assessors (detection bias); incomplete outcome data addressed (attrition bias); selective outcome reporting (reporting bias); and other bias types. The overall risk of bias of the included trials was assessed according to the following criteria: low risk of bias - if all fields were assessed as low risk of bias; unclear risk of bias - if at least 1 field was assessed as unclear risk of bias; and high risk of bias - if at least 1 field was assessed as high risk of bias.

\section{Synthesis of results and statistical analysis}

Relevant data related to the previously stated variables was collected and organized into tables. No meta-analyses could be performed due to the heterogeneity of study designs, treatment protocols and outcomes.

\section{Results}

\section{Study selection}

Article review and data extraction was performed according to the PRISMA flow diagram. The initial search identified a total of 54,013 references. Following the screening of the article titles, 304 potentially relevant articles were identified. Independent screening of the abstracts resulted in the selection of 23 publications and 1 protocol (for ongoing study) for possible inclusion. The inclusion and exclusion criteria were applied to the 23 full-text articles. Finally, 8 articles that met the predefined criteria were included in the current systematic review. The PRISMA flow chart (Fig. 1) illustrates the search methodology and results.

\section{Exclusion of studies}

The reasons for excluding studies after full-text assessment were as follows: use of non-human enamel $(n=1)$, in vitro studies $(n=4)$, the clinical aspect not applied through orthodontic treatment $(n=7)$, studies on primary teeth $(n=1)$, full text non-available $(n=2)$. The excluded studies, together with the reasons of excluding, are outlined in Supplementary Material 2.

\section{Quality assessment}

The quality assessment of the included studies revealed unclear risk of bias (for 1 or more key domains) in the 8 studies included. Blinding of participants and blinding during outcome assessment were the most problematic fields (unclear risk of bias in $87.5 \%$ and $75 \%$ of studies, respectively). The overall risk of bias for the included studies is summarized in Fig. 2 and 3.

\section{Study characteristics}

The studies were compared regarding the sample size, study design, type and parameters of the laser applied, and the main outcomes. The 8 articles were published between 2000 and 2015. They involved 183 patients, and the main inclusion criterion was healthy patients in need of orthodontic treatment without caries, demineralization or restorations on the facial surfaces of teeth, except for the trial by Harazaki et al., which included orthodontic patients with early demineralization. ${ }^{13}$ Intervention in all trials was the application of different laser types; 4 studies applied an argon laser, 2 studies applied a $\mathrm{CO}_{2}$ laser, 1 study applied an Nd:YAG laser, and 1 study applied an Optodan ${ }^{\circledR}$ laser. The characteristics of the 8 studies are summarized in Table 2.

\section{Results of individual studies}

Four clinical studies applied an argon laser ${ }^{14-17}$ and 3 of them reported a significant reduction in the lesion depth, measured on microphotographs of the polarized light microscopy, for the argon laser-irradiated groups of teeth compared to the control groups ( $p \leq 0.05) .{ }^{14-16}$ One study did not find a significant effect of argon laser curing on enamel WSL formation, evaluated on the basis of photographs, in the laser group compared to the control group $(\mathrm{p} \geq 0.05){ }^{17}$

Two studies applied a $\mathrm{CO}_{2}$ laser to enamel around orthodontic brackets and reported that $\mathrm{CO}_{2}$ laser irradiation produced marked demineralization inhibition in short and medium follow-up terms, as it led to significantly higher enamel microhardness compared to the control non-irradiated enamel ( $\mathrm{p} \leq 0.04) .{ }^{18,19}$

One clinical study applied an Nd:YAG laser to enamel with WSLs and showed that it was effective in inhibiting the development of dental caries, as the increase of the WSL area was significantly lower compared to the control group $(\mathrm{p} \leq 0.05) .{ }^{13}$

One clinical trial used an Optodan low-intensity laser around orthodontic brackets and reported that the growth index in dental and surface caries intensity was significantly lower in the laser therapy group than in the control group ( $\mathrm{p} \leq 0.001) .{ }^{20}$ The results of the studies included are summarized in Table 3. 


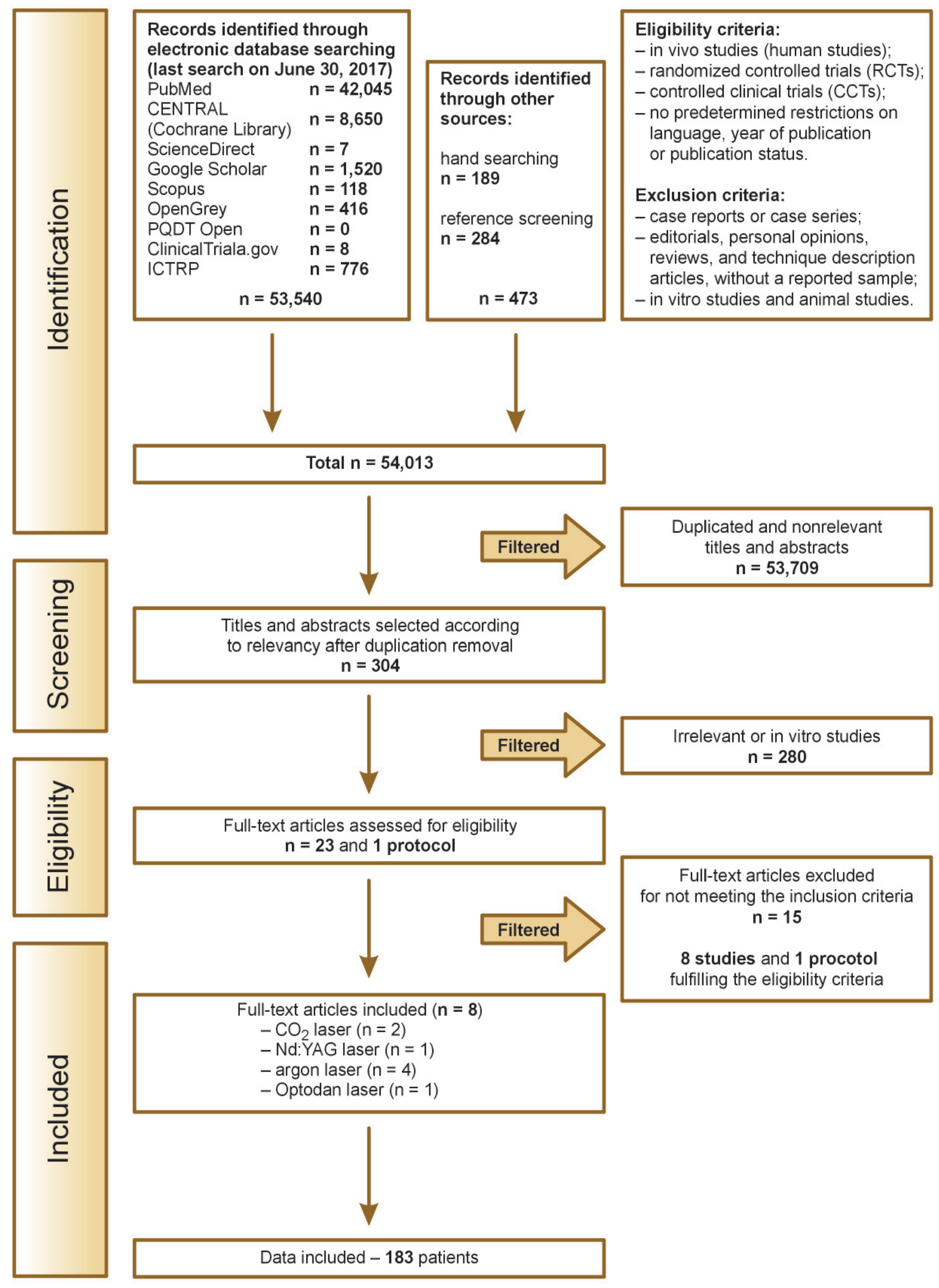

Fig. 1. PRISMA flow diagram illustrating the literature search protocol

PRISMA - Preferred Reporting Items for Systematic Reviews and Meta-Analyses. 
Supplementary Material 2. Studies excluded after full text reading with the reasons of excluding

\section{Study}

Reason of excluding

Souza-Gabriel AE, Turssi CP, Colucci V, Tenuta LM, Serra MC, Corona SA. In situ study of the anticariogenic potential of

fluoride varnish combined with $\mathrm{CO}_{2}$ laser on enamel. Arch Oral Biol. 2015;60(6):804-810.

Stangler LP, Romano FL, Shirozaki MU, et al. Microhardness of enamel adjacent to orthodontic brackets after $\mathrm{CO}_{2}$ laser

non-human enamel irradiation and fluoride application. Braz Dent J. 2013;24(5):508-512.

Seino PY, Freitas PM, Marques MM, de Souza Almeida FC, Botta SB, Moreira MS. Influence of $\mathrm{CO}_{2}(10.6 \mu \mathrm{m})$ and Nd:YAG laser irradiation on the prevention of enamel caries around orthodontic brackets. Lasers Med Sci. 2015;30(2):611-616.

in vitro study

in vitro study

Kantorowitz Z, Featherstone JD, Fried D. Caries prevention by $\mathrm{CO}_{2}$ laser treatment: Dependency on the number of pulses used. J Am Dent Assoc. 1998;129(5):585-591.

Lara-Carrilloa E, Doroteo-Chimalb C, Lopez-Gonzaleza S, et al. Remineralization effect of low-level laser and amorphous sodium-calcium-phosphosilicate paste in teeth with fixed orthodontic appliances. Tanta Dental Journal. 2016;13(1):55-62.

Zezell DM, Boari HGD, Ana PA, Eduardo Cde P, Powell GL. Nd:YAG laser in caries prevention: A clinical trial. Lasers Surg Med. 2009;41(1):31-35.

Correa-Afonso AM, Pécora JD, Palma-Dibb RG. Influence of laser irradiation on pits and fissures: An in situ study. Photomed Laser Surg. 2013;31(2):82-89.

Nammour S, Demortier G, Florio P, et al. Increase of enamel fluoride retention by low fluence argon laser in vivo. Lasers Surg Med. 2003;33(4):260-263.

Nammour S, Rocca JP, Pireaux JJ, Powell G, Morciaux Y, Demortir G. Increase of enamel fluoride retention by low fluence argon laser beam: A 6-month follow-up study in vivo. Lasers Surg Med. 2005;36(3):220-224.

Apel C, Birker L, Meister J, Weiss C, Gutknecht N. The caries-preventive potential of subablative Er:YAG and Er:YSGG laser radiation in an intraoral model: A pilot study. Photomed Laser Surg. 2004;22(4):312-317.

Korytnicki D, Mayer MP, Daronch M, Singer Jda M, Grande RH. Effects of Nd:YAG laser on enamel microhardness and dental plaque composition: An in situ study. Photomed Laser Surg. 2006;24(1):59-63.

Rechmann P, Charland DA, Rechmann BM, Le CQ, Featherstone JD. In vivo occlusal caries prevention by pulsed $\mathrm{CO}_{2}$ laser and fluoride varnish treatment: A clinical pilot study. Lasers Surg Med. 2013;45(5):302-310.

Raucci-Neto W, de Castro-Raucci LM, Lepri CP, Faraoni-Romano Jل J, Gomes da Silva JM, Palma-Dibb RG. Nd:YAG laser in occlusal caries prevention of primary teeth: A randomized clinical trial. Lasers Med Sci. 2015;30(2):761-768.

Jacobson A. The effect of argon laser irradiation on reducing enamel decalcification during orthodontic treatment: An in vitro and in vivo study. Am J Orthod Dentofacial Orthop. 2006;129(1):82.

Rodrigues L, Parisotto T, Steiner-Oliveira C, Azevedo L, Tabchoury C. Effect of $\mathrm{CO}_{2}$ laser and fluoride dentifrice on demineralization around orthodontic brackets: An in situ study. Lasers Surg Med. 2014;46:57 in vitro study

in vitro study

clinical study, but not applied during orthodontic treatment

clinical study, but not applied during orthodontic treatment

clinical study, but not applied during orthodontic treatment clinical study, but not applied during orthodontic treatment clinical study, but not applied during orthodontic treatment clinical study, but not applied during orthodontic treatment clinical study, but not applied during orthodontic treatment

study on primary teeth

full text non-available

full text non-available

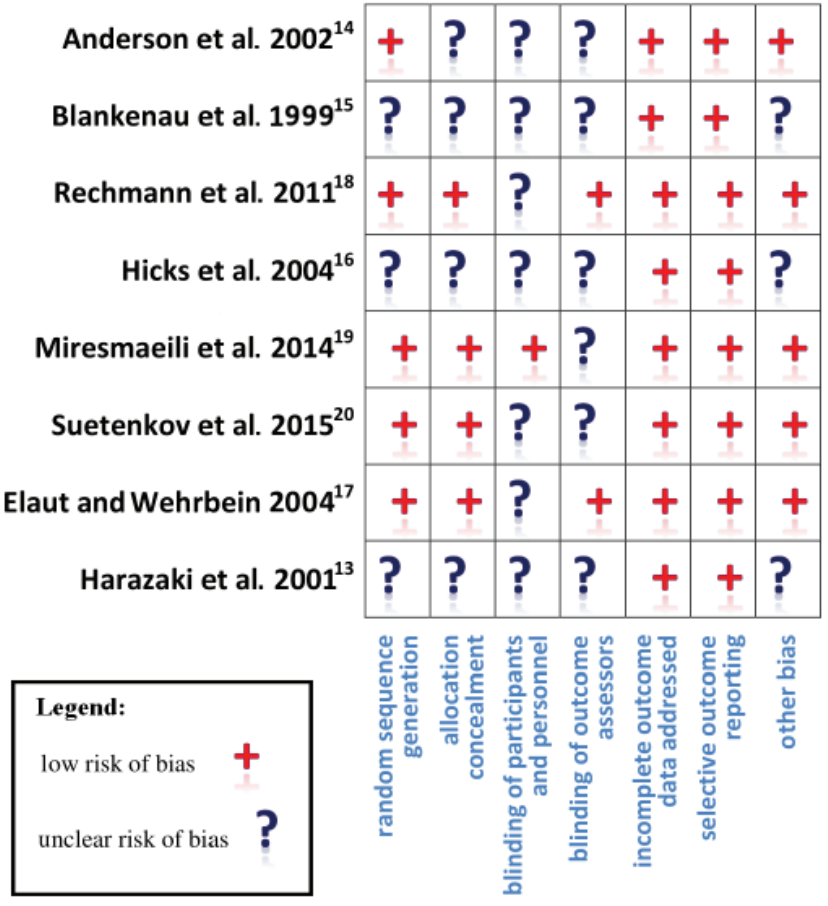

Fig. 2. Summary of the risk of bias for the studies included

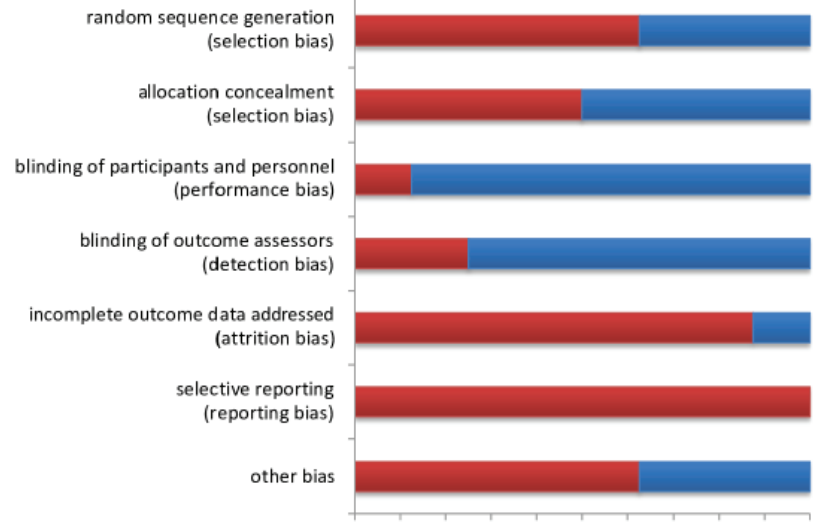

$0 \% \quad 10 \% \quad 20 \% 30 \%$ 40\% 50\% 60\% 70\% 80\% 90\% 100\%

- unclear risk of bias 
Table 2. Characteristics of the trials included

\begin{tabular}{|c|c|c|c|c|c|c|c|c|c|}
\hline \multirow[b]{2}{*}{ Study } & \multicolumn{2}{|r|}{ Methods } & \multirow[b]{2}{*}{ Participants } & \multicolumn{3}{|c|}{ Intervention } & \multirow[b]{2}{*}{ Follow-up time } & \multirow[b]{2}{*}{ Primary outcomes } & \multirow[b]{2}{*}{$\begin{array}{l}\text { Methods of measurement } \\
\text { of primary outcomes }\end{array}$} \\
\hline & $\begin{array}{l}\text { study } \\
\text { design }\end{array}$ & treatment comparison & & $\begin{array}{c}\text { type } \\
\text { of laser } \\
\text { beam }\end{array}$ & laser parameters & details of irradiation protocol & & & \\
\hline $\begin{array}{l}\text { Anderson } \\
\text { et al. } \\
2002^{14}\end{array}$ & RCT & $\begin{array}{l}\text { amount of decalcification in the } \\
\text { control group and the argon } \\
\text { laser-iradiated groups of teeth } \\
\text { (non-pumiced-non-etched } \\
\text { group, pumiced group and } \\
\text { etched group) }\end{array}$ & $\begin{array}{l}9 \text { patients scheduled for orthodontic treatment with the extraction of } 4 \text { premolars; } \\
36 \text { premolars allocated in } 4 \text { groups } \\
\text { (inclusion criteria: teeth without enamel defects or decalcification) }\end{array}$ & $\begin{array}{l}\text { argon } \\
\text { laser }\end{array}$ & 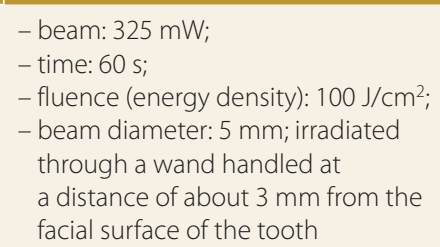 & $\begin{array}{l}\text { in } 3 \text { lased groups, the laser was applied } \\
\text { alone or after pumicing or after pumicing } \\
\text { and etching; then modified orthodontic } \\
\text { bands with pockets to plaque accumulation } \\
\text { were fitted on the premolars }\end{array}$ & $\begin{array}{l}5 \text { weeks; then the teeth } \\
\text { were extracted }\end{array}$ & $\begin{array}{l}\text { lesion depth } \\
\text { measurement [um]; lesion } \\
\text { area measurement [um²] }\end{array}$ & $\begin{array}{l}\text { polarized light microscopy } \\
\text { - digital microscope images } \\
\text { were examined and measured }\end{array}$ \\
\hline $\begin{array}{l}\text { Blankenau } \\
\text { et al. } \\
1999^{15}\end{array}$ & $\begin{array}{l}\text { inical pilot } \\
\text { study }\end{array}$ & $\begin{array}{l}\text { demineralization of enamel in } \\
\text { the laser-irradiated and control } \\
\text { teeth }\end{array}$ & $\begin{array}{l}4 \text { patients needing orthodontic treatment with bilateral premolar extraction; } \\
4 \text { pairs of premolars from each participant (1 experimental and } 3 \text { controll) }\end{array}$ & $\begin{array}{c}\text { argon } \\
\text { laser }\end{array}$ & $\begin{array}{l}\text { - beam: } 250 \mathrm{~mW} ; \\
\text { - time: } 10 \mathrm{~mW}_{i} \\
\text { - fluence: } 12 \mathrm{~J} / \mathrm{cm}^{2} ; \\
\text { - beam diameter: } 5 \mathrm{~mm}\end{array}$ & $\begin{array}{l}\text { after experimental teeth irradiation, } \\
\text { modified orthodontic bands were fitted on } \\
\text { the lased and control teeth }\end{array}$ & $\begin{array}{l}5 \text { weeks; then the teeth } \\
\text { were extracted }\end{array}$ & lesion depth & polarized light microscopy \\
\hline $\begin{array}{l}\text { Elaut and } \\
\text { Wehrbein } \\
\text { 2004 }\end{array}$ & RCT (SP) & $\begin{array}{l}\text { bracket bonding failure and } \\
\text { enamel decalcification in argon } \\
\text { laser-cured and conventional } \\
\text { light-cured bracket adhesives } \\
\text { through orthodontic treatment }\end{array}$ & 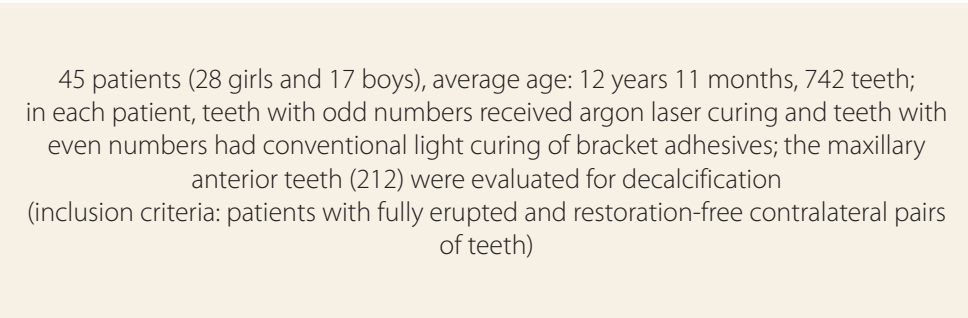 & $\begin{array}{c}\text { argon } \\
\text { laser }\end{array}$ & $\begin{array}{l}\text { - beam: } 250 \mathrm{~mm} \text { (continuous mode) } \\
\text { - time } 5 \mathrm{~s} \text { sfom the incisal side and } \\
5 \mathrm{~s} \text { from the gingival side; } \\
- \text { fluence: } 12 \mathrm{~J} / \mathrm{cm} \text {; } \\
\text { - beam diameter: } 5 \mathrm{~mm}\end{array}$ & $\begin{array}{l}\text { thermoformed plastic/aluminium foil was } \\
\text { used to cover the control teeth during } \\
\text { argon laser curing }\end{array}$ & $\begin{array}{l}14 \text { months for enamel } \\
\text { decalcification (after } \\
\text { removing brackets from } \\
\text { the maxillary anterior } \\
\text { teeth), } 12 \text { months for } \\
\text { plaque accumulation; } \\
\text { the bonding fallure rate } \\
\text { was evaluated for } 4-5 \\
\text { weeks after bonding }\end{array}$ & $\begin{array}{l}\text { absence or degree } \\
\text { of WLLs on enamel on the } \\
\text { facial surfaces of maxillary } \\
\text { anterior teeth; plaque } \\
\text { accumulation on the } \\
\text { maxillary anterior teeth; } \\
\text { the bonding failure rate } \\
\text { during the study period }\end{array}$ & $\begin{array}{l}\text { enamel decalcification and } \\
\text { plaque accumulation were } \\
\text { evaluated through comparing } \\
\text { digital images before and } \\
\text { after the study period by } \\
\text { a team of } 7 \text { examiners }\end{array}$ \\
\hline $\begin{array}{l}\text { Harazaki } \\
\text { et al. } \\
2001^{13}\end{array}$ & clinical trial & $\begin{array}{l}\text { increase in WSLs in the laser- } \\
\text { irradiated and the control } \\
\text { patients; enamel changes } \\
\text { in the irradiated and non- } \\
\text { manipulated parts of enamel } \\
\text { of the premolar }\end{array}$ & $\begin{array}{l}\text { in vivo part of the study: } 10 \text { patients undergoing orthodontic treatment, } \\
\text { with enamel WSLL on their teetht, the other } 10 \text { patients were a control group; } \\
\text { the focus was on maxilary incisors } \\
\text { in vitro part of the study: laser irradiation was applied to } 1 \text { extracted premolar }\end{array}$ & $\begin{array}{c}\text { Nd:YAG } \\
\text { laser }\end{array}$ & $\begin{array}{l}\text { - pulse width: } 0.3 \mathrm{~ms} ; \\
\text { - pulse energy: } 0.75 \mathrm{~J} ; \\
\text { - power: } 2 \times 10 \mathrm{~W} ; \\
\text { - repeated } 20 \mathrm{pps} ; \\
\text { - time: } 5 \mathrm{~s} ; \\
\text { - fluence: } 40 \mathrm{~J} / \mathrm{cm}^{2}\end{array}$ & 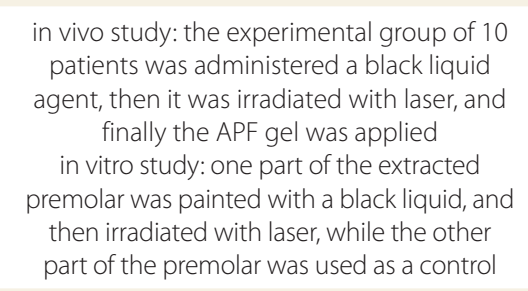 & 1 year & $\begin{array}{l}\text { increase in the area } \\
\text { of WLLs safter 1 year in the } \\
\text { experimental and control } \\
\text { groups; enamel surface } \\
\text { changes in the irradiated } \\
\text { and control parts of the } \\
\text { extracted premolar }\end{array}$ & $\begin{array}{l}\text { WSLs were traced by taking } \\
\text { photographs and with tracing } \\
\text { paper, and the total WSL area } \\
\text { was calculated before laser } \\
\text { irradiation and after } 1 \text { year; } \\
\text { enamel surface changes were } \\
\text { observed by SEM }\end{array}$ \\
\hline $\begin{array}{l}\text { Hicks et al. } \\
2004^{16}\end{array}$ & $\begin{array}{l}\text { clinical pilot } \\
\text { study }\end{array}$ & $\begin{array}{l}\text { lesion depth in argon laser } \\
\text { iirradiated-teeth in the argon } \\
\text { and fluoride group and the } \\
\text { control (non-treatment) group }\end{array}$ & $\begin{array}{l}5 \text { patients ( } 3 \text { females, } 2 \text { males), age: 19-28 years, requiring orthodontic treatment } \\
\text { with tooth extraction (14 teeth); the teeth were caries-free on the buccal surfaces }\end{array}$ & $\begin{array}{l}\text { argon } \\
\text { laser }\end{array}$ & $\begin{array}{l}\text { - beam: } 250 \mathrm{~mW} ; \\
\text { - time: } 10 \mathrm{~s} ; \\
\text { - fluence: } 12 \mathrm{~J} / \mathrm{cm}^{2}\end{array}$ & $\begin{array}{l}\text { the teeth were assigned in } 3 \text { groups: argon } \\
\text { laser, topical fluoride followeded by argon laser } \\
\text { irradiation, and no treatment (Control), then } \\
\text { modified orthodontic abands with plaque } \\
\text { retentive slots were placed on the teeth }\end{array}$ & $\begin{array}{l}5 \text { weeks; then the teeth } \\
\text { were extracted }\end{array}$ & $\begin{array}{l}\text { lesion depth in the } 3 \\
\text { groups }\end{array}$ & polarised light microscopy \\
\hline $\begin{array}{l}\text { Miresmaeili } \\
\text { et al. } \\
2014^{19}\end{array}$ & $\mathrm{RCT}(\mathrm{SP})$ & $\begin{array}{l}\text { enamel surface microhardness } \\
\text { in the treated and control } \\
\text { premolars }\end{array}$ & 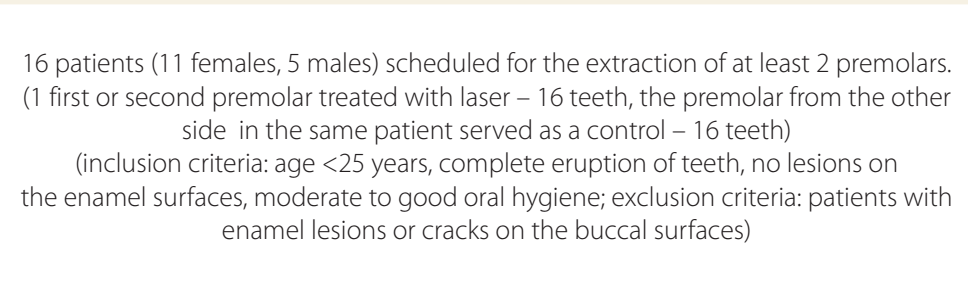 & $\mathrm{CO}_{2}$ laser & $\begin{array}{l}\text { - wave length: } 10.6 \mathrm{Hm} ; \\
\text { - pulse enuration: } 5 \mathrm{si} ; \\
\text { - pulse repetition rate: } 5 \mathrm{~Hz} ; \\
\text { - beam diameter: } 0.2 \mathrm{~mm} ; \\
\text { - power: } 0.7 \mathrm{~W}\end{array}$ & $\begin{array}{l}\text { the experimental teeth were irradiated } \\
\text { with laser and the control premolars } \\
\text { were exposed to non-theraputic lirht; } \\
\text { then orthodontic brackets were attached } \\
\text { to both premolars and the - Tloop was } \\
\text { engaged to the brackets to increase plaque } \\
\text { accumulation }\end{array}$ & $\begin{array}{l}\text { at least } 2 \text { months } \\
\text { after laser irradiation, } \\
\text { then the teeth were } \\
\text { extracted ( } 1 \text { tooth } \\
\text { from each group was } \\
\text { extracted after } 1 \text { week } \\
\text { of laser irradiation for } \\
\text { the SEM evaluation) }\end{array}$ & $\begin{array}{l}\text { enamel surface } \\
\text { microhardness around } \\
\text { orthodontic brackets; } \\
\text { enamel surface changes } \\
\text { after laser therapy }\end{array}$ & $\begin{array}{l}\text { Vickers diamond microhardness } \\
\text { testing machine was used } \\
\text { to evaluate enamel surface } \\
\text { microhardness; SEM was used } \\
\text { to observe enamel surface } \\
\text { changes }\end{array}$ \\
\hline $\begin{array}{l}\text { Rechmann } \\
\text { et al. } \\
2011^{18}\end{array}$ & $\begin{array}{l}\mathrm{RCT} \\
(\mathrm{PG})\end{array}$ & $\begin{array}{l}\text { enamel demineralization } \\
\text { around orthdontic brackets in } \\
\text { the laser-irradiated area and } \\
\text { other area in the same tooth as } \\
\text { a control }\end{array}$ & $\begin{array}{l}24 \text { patients } \\
\text { (13 females, } 11 \text { maless), average age: } 14.9 \pm 2.2 \text { years, randomly assigned to } 4 \text {-week } \\
\text { (average age: } 14.6 \pm 2.3 \text { years) and } 12 \text {-week (average age: } 15.2 \pm 2.1 \text { years) study arms } \\
\text { (inclusion criteria: healthy patients, ageded } 122-18 \text { years, scheduled to premolar } \\
\text { for orthodontic reasons, teeth withoutraction caries or restorations on the facial surface; } \\
\text { exclusion criteria: systematic diseases, medication affecting oral flora or salivary flow, } \\
\text { fluoride treatment in the last } 3 \text { months) }\end{array}$ & $\mathrm{CO}_{2}$ laser & 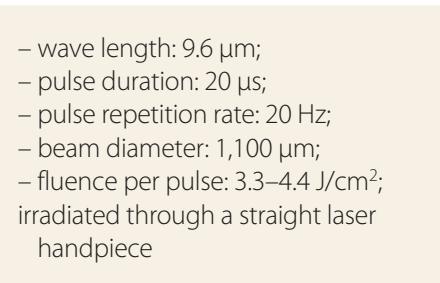 & $\begin{array}{l}\text { the laser beam was applied on enamel, } \\
\text { cervical to the bracket of the premolar on } \\
\text { one side of an imaginary line, perpendicular } \\
\text { to the brackest slot, while the other side } \\
\text { of the line in the same tooth served as } \\
\text { a controli each spot of the testing area } \\
\text { was irradiated with } 20 \text { pulses and laser } \\
\text { irradiation was applied only once }\end{array}$ & $\begin{array}{l}4 \text { weeks for one group } \\
(12 \text { patients) and } \\
12 \text { weeks for the other } \\
\text { group (12 patients); } \\
\text { then the teeth were } \\
\text { extracted }\end{array}$ & $\begin{array}{c}\text { overall relative mineral } \\
\text { loss in the 4-week and } \\
12 \text {-week arms in the } \\
\text { irradiated and control } \\
\text { enamel }\end{array}$ & $\begin{array}{l}\text { cross-sectional microhardness } \\
\text { testing }\end{array}$ \\
\hline $\begin{array}{l}\text { Suetenkov } \\
\text { et al. } \\
2015^{20}\end{array}$ & RCT & $\begin{array}{l}\text { dental caries and oral hygiene } \\
\text { in the group with traditional } \\
\text { preventive measures and the } \\
\text { group with laser therapy and } \\
\text { traditional preventive measures }\end{array}$ & $\begin{array}{l}60 \text { patients (20 girls, } 40 \text { boys), age: } 12-13 \text { years, } \\
\text { divided into } 2 \text { groups (30 patients in each group) }\end{array}$ & $\begin{array}{l}\text { Optodan } \\
\text { (low- } \\
\text { intensity) } \\
\text { laser }\end{array}$ & $\begin{array}{l}\text { - wave length: } \\
\text { - } .98-0.85 \mathrm{~nm} ; \\
\text { - power: } 0.5-1.0 \mathrm{~W} ; \\
\text { - pulse repetition rate: } 2000 \mathrm{~Hz} ; \\
\text { - time: } 2 \text { min for each segment }\end{array}$ & $\begin{array}{l}\text { the irradiated area included } 2 \text { segments } \\
\text { (upper and lower teeth aligments); } \\
\text { irradiation was applied after professional } \\
\text { oral hyggiene measures were taken, and } \\
\text { there were } 4 \text { courses per year, every } \\
3 \text { months }\end{array}$ & $\begin{array}{l}1 \text { year (after } \\
\text { orthodontic treatment } \\
\text { completion and } \\
\text { removing orthodontic } \\
\text { brackets) }\end{array}$ & $\begin{array}{l}\text { oral hygiene and caries } \\
\text { intensity before and after } \\
\text { orthodontic treatment in } \\
\text { both groups }\end{array}$ & $\begin{array}{l}\text { visual examination to } \\
\text { determine OHI-S, } \\
\text { DMFT index and DMFS index } \\
\text { before and after the treatment } \\
\text { for both groups }\end{array}$ \\
\hline
\end{tabular}

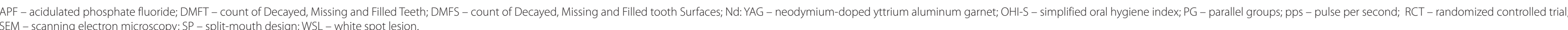


Table 2. Characteristics of the trials included

\begin{tabular}{|c|c|c|c|c|c|c|c|c|c|}
\hline \multirow[b]{2}{*}{ Study } & \multicolumn{2}{|r|}{ Methods } & \multirow[b]{2}{*}{ Participants } & \multicolumn{3}{|c|}{ Intervention } & \multirow[b]{2}{*}{ Follow-up time } & \multirow[b]{2}{*}{ Primary outcomes } & \multirow[b]{2}{*}{$\begin{array}{l}\text { Methods of measurement } \\
\text { of primary outcomes }\end{array}$} \\
\hline & $\begin{array}{l}\text { study } \\
\text { design }\end{array}$ & treatment comparison & & $\begin{array}{c}\text { type } \\
\text { of laser } \\
\text { beam }\end{array}$ & laser parameters & details of irradiation protocol & & & \\
\hline $\begin{array}{l}\text { Anderson } \\
\text { et al. } \\
2002^{14}\end{array}$ & RCT & $\begin{array}{l}\text { amount of decalcification in the } \\
\text { control group and the argon } \\
\text { laser-iradiated groups of teeth } \\
\text { (non-pumiced-non-etched } \\
\text { group, pumiced group and } \\
\text { etched group) }\end{array}$ & $\begin{array}{l}9 \text { patients scheduled for orthodontic treatment with the extraction of } 4 \text { premolars; } \\
36 \text { premolars allocated in } 4 \text { groups } \\
\text { (inclusion criteria: teeth without enamel defects or decalcification) }\end{array}$ & $\begin{array}{l}\text { argon } \\
\text { laser }\end{array}$ & 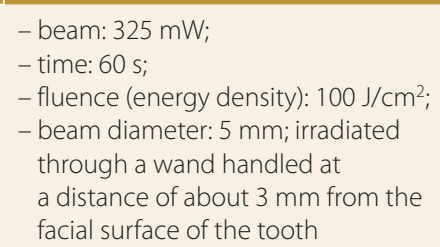 & $\begin{array}{l}\text { in } 3 \text { lased groups, the laser was applied } \\
\text { alone or after pumicing or after pumicing } \\
\text { and etching; then modified orthodontic } \\
\text { bands with pockets to plaque accumulation } \\
\text { were fitted on the premolars }\end{array}$ & $\begin{array}{l}5 \text { weeks; then the teeth } \\
\text { were extracted }\end{array}$ & $\begin{array}{l}\text { lesion depth } \\
\text { measurement [um]; lesion } \\
\text { area measurement [um²] }\end{array}$ & $\begin{array}{l}\text { polarized light microscopy } \\
\text { - digital microscope images } \\
\text { were examined and measured }\end{array}$ \\
\hline $\begin{array}{l}\text { Blankenau } \\
\text { et al. } \\
1999^{15}\end{array}$ & $\begin{array}{l}\text { inical pilot } \\
\text { study }\end{array}$ & $\begin{array}{l}\text { demineralization of enamel in } \\
\text { the laser-irradiated and control } \\
\text { teeth }\end{array}$ & $\begin{array}{l}4 \text { patients needing orthodontic treatment with bilateral premolar extraction; } \\
4 \text { pairs of premolars from each participant (1 experimental and } 3 \text { controll) }\end{array}$ & $\begin{array}{c}\text { argon } \\
\text { laser }\end{array}$ & $\begin{array}{l}\text { - beam: } 250 \mathrm{~mW} ; \\
\text { - time: } 10 \mathrm{~mW}_{i} \\
\text { - fluence: } 12 \mathrm{~J} / \mathrm{cm}^{2} ; \\
\text { - beam diameter: } 5 \mathrm{~mm}\end{array}$ & $\begin{array}{l}\text { after experimental teeth irradiation, } \\
\text { modified orthodontic bands were fitted on } \\
\text { the lased and control teeth }\end{array}$ & $\begin{array}{l}5 \text { weeks; then the teeth } \\
\text { were extracted }\end{array}$ & lesion depth & polarized light microscopy \\
\hline $\begin{array}{l}\text { Elaut and } \\
\text { Wehrbein } \\
\text { 2004 }\end{array}$ & RCT (SP) & $\begin{array}{l}\text { bracket bonding failure and } \\
\text { enamel decalcification in argon } \\
\text { laser-cured and conventional } \\
\text { light-cured bracket adhesives } \\
\text { through orthodontic treatment }\end{array}$ & 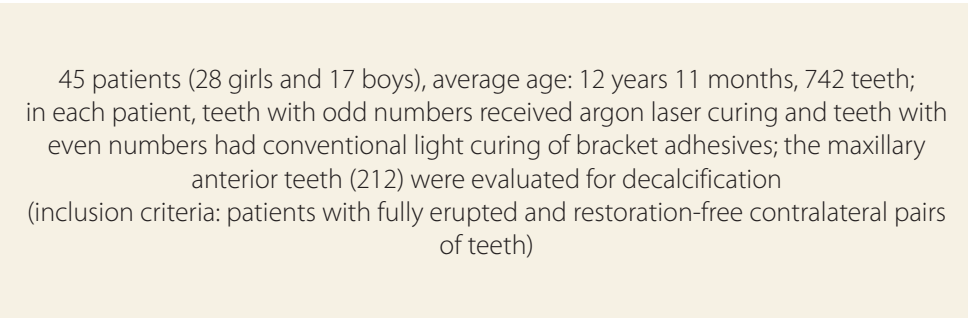 & $\begin{array}{c}\text { argon } \\
\text { laser }\end{array}$ & $\begin{array}{l}\text { - beam: } 250 \mathrm{~mm} \text { (continuous mode) } \\
\text { - time } 5 \mathrm{~s} \text { sfom the incisal side and } \\
5 \mathrm{~s} \text { from the gingival side; } \\
- \text { fluence: } 12 \mathrm{~J} / \mathrm{cm} \text {; } \\
\text { - beam diameter: } 5 \mathrm{~mm}\end{array}$ & $\begin{array}{l}\text { thermoformed plastic/aluminium foil was } \\
\text { used to cover the control teeth during } \\
\text { argon laser curing }\end{array}$ & $\begin{array}{l}14 \text { months for enamel } \\
\text { decalcification (after } \\
\text { removing brackets from } \\
\text { the maxillary anterior } \\
\text { teeth), } 12 \text { months for } \\
\text { plaque accumulation; } \\
\text { the bonding fallure rate } \\
\text { was evaluated for } 4-5 \\
\text { weeks after bonding }\end{array}$ & $\begin{array}{l}\text { absence or degree } \\
\text { of WLLs on enamel on the } \\
\text { facial surfaces of maxillary } \\
\text { anterior teeth; plaque } \\
\text { accumulation on the } \\
\text { maxillary anterior teeth; } \\
\text { the bonding failure rate } \\
\text { during the study period }\end{array}$ & $\begin{array}{l}\text { enamel decalcification and } \\
\text { plaque accumulation were } \\
\text { evaluated through comparing } \\
\text { digital images before and } \\
\text { after the study period by } \\
\text { a team of } 7 \text { examiners }\end{array}$ \\
\hline $\begin{array}{l}\text { Harazaki } \\
\text { et al. } \\
2001^{13}\end{array}$ & clinical trial & $\begin{array}{l}\text { increase in WSLs in the laser- } \\
\text { irradiated and the control } \\
\text { patients; enamel changes } \\
\text { in the irradiated and non- } \\
\text { manipulated parts of enamel } \\
\text { of the premolar }\end{array}$ & $\begin{array}{l}\text { in vivo part of the study: } 10 \text { patients undergoing orthodontic treatment, } \\
\text { with enamel WSLL on their teetht, the other } 10 \text { patients were a control group; } \\
\text { the focus was on maxilary incisors } \\
\text { in vitro part of the study: laser irradiation was applied to } 1 \text { extracted premolar }\end{array}$ & $\begin{array}{c}\text { Nd:YAG } \\
\text { laser }\end{array}$ & $\begin{array}{l}\text { - pulse width: } 0.3 \mathrm{~ms} ; \\
\text { - pulse energy: } 0.75 \mathrm{~J} ; \\
\text { - power: } 2 \times 10 \mathrm{~W} ; \\
\text { - repeated } 20 \mathrm{pps} ; \\
\text { - time: } 5 \mathrm{~s} ; \\
\text { - fluence: } 40 \mathrm{~J} / \mathrm{cm}^{2}\end{array}$ & 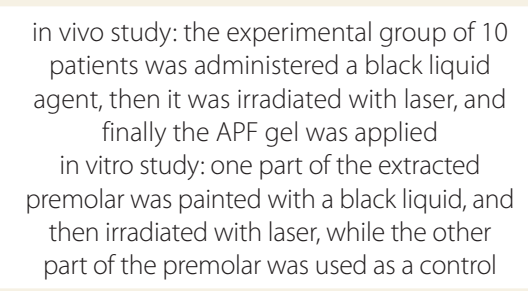 & 1 year & $\begin{array}{l}\text { increase in the area } \\
\text { of WLLs safter 1 year in the } \\
\text { experimental and control } \\
\text { groups; enamel surface } \\
\text { changes in the irradiated } \\
\text { and control parts of the } \\
\text { extracted premolar }\end{array}$ & $\begin{array}{l}\text { WSLs were traced by taking } \\
\text { photographs and with tracing } \\
\text { paper, and the total WSL area } \\
\text { was calculated before laser } \\
\text { irradiation and after } 1 \text { year; } \\
\text { enamel surface changes were } \\
\text { observed by SEM }\end{array}$ \\
\hline $\begin{array}{l}\text { Hicks et al. } \\
2004^{16}\end{array}$ & $\begin{array}{l}\text { clinical pilot } \\
\text { study }\end{array}$ & $\begin{array}{l}\text { lesion depth in argon laser } \\
\text { iirradiated-teeth in the argon } \\
\text { and fluoride group and the } \\
\text { control (non-treatment) group }\end{array}$ & $\begin{array}{l}5 \text { patients ( } 3 \text { females, } 2 \text { males), age: 19-28 years, requiring orthodontic treatment } \\
\text { with tooth extraction (14 teeth); the teeth were caries-free on the buccal surfaces }\end{array}$ & $\begin{array}{l}\text { argon } \\
\text { laser }\end{array}$ & $\begin{array}{l}\text { - beam: } 250 \mathrm{~mW} ; \\
\text { - time: } 10 \mathrm{~s} ; \\
\text { - fluence: } 12 \mathrm{~J} / \mathrm{cm}^{2}\end{array}$ & $\begin{array}{l}\text { the teeth were assigned in } 3 \text { groups: argon } \\
\text { laser, topical fluoride followeded by argon laser } \\
\text { irradiation, and no treatment (Control), then } \\
\text { modified orthodontic abands with plaque } \\
\text { retentive slots were placed on the teeth }\end{array}$ & $\begin{array}{l}5 \text { weeks; then the teeth } \\
\text { were extracted }\end{array}$ & $\begin{array}{l}\text { lesion depth in the } 3 \\
\text { groups }\end{array}$ & polarised light microscopy \\
\hline $\begin{array}{l}\text { Miresmaeili } \\
\text { et al. } \\
2014^{19}\end{array}$ & $\mathrm{RCT}(\mathrm{SP})$ & $\begin{array}{l}\text { enamel surface microhardness } \\
\text { in the treated and control } \\
\text { premolars }\end{array}$ & 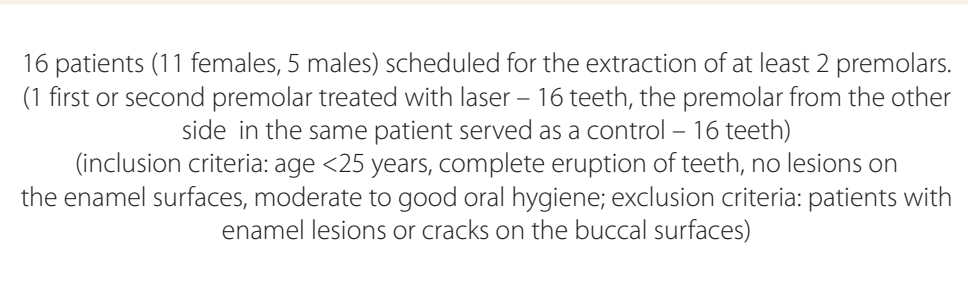 & $\mathrm{CO}_{2}$ laser & $\begin{array}{l}\text { - wave length: } 10.6 \mathrm{Hm} ; \\
\text { - pulse enuration: } 5 \mathrm{si} ; \\
\text { - pulse repetition rate: } 5 \mathrm{~Hz} ; \\
\text { - beam diameter: } 0.2 \mathrm{~mm} ; \\
\text { - power: } 0.7 \mathrm{~W}\end{array}$ & $\begin{array}{l}\text { the experimental teeth were irradiated } \\
\text { with laser and the control premolars } \\
\text { were exposed to non-theraputic lirht; } \\
\text { then orthodontic brackets were attached } \\
\text { to both premolars and the - Tloop was } \\
\text { engaged to the brackets to increase plaque } \\
\text { accumulation }\end{array}$ & $\begin{array}{l}\text { at least } 2 \text { months } \\
\text { after laser irradiation, } \\
\text { then the teeth were } \\
\text { extracted ( } 1 \text { tooth } \\
\text { from each group was } \\
\text { extracted after } 1 \text { week } \\
\text { of laser irradiation for } \\
\text { the SEM evaluation) }\end{array}$ & $\begin{array}{l}\text { enamel surface } \\
\text { microhardness around } \\
\text { orthodontic brackets; } \\
\text { enamel surface changes } \\
\text { after laser therapy }\end{array}$ & $\begin{array}{l}\text { Vickers diamond microhardness } \\
\text { testing machine was used } \\
\text { to evaluate enamel surface } \\
\text { microhardness; SEM was used } \\
\text { to observe enamel surface } \\
\text { changes }\end{array}$ \\
\hline $\begin{array}{l}\text { Rechmann } \\
\text { et al. } \\
2011^{18}\end{array}$ & $\begin{array}{l}\mathrm{RCT} \\
(\mathrm{PG})\end{array}$ & $\begin{array}{l}\text { enamel demineralization } \\
\text { around orthdontic brackets in } \\
\text { the laser-irradiated area and } \\
\text { other area in the same tooth as } \\
\text { a control }\end{array}$ & $\begin{array}{l}24 \text { patients } \\
\text { (13 females, } 11 \text { maless), average age: } 14.9 \pm 2.2 \text { years, randomly assigned to } 4 \text {-week } \\
\text { (average age: } 14.6 \pm 2.3 \text { years) and } 12 \text {-week (average age: } 15.2 \pm 2.1 \text { years) study arms } \\
\text { (inclusion criteria: healthy patients, ageded } 122-18 \text { years, scheduled to premolar } \\
\text { for orthodontic reasons, teeth withoutraction caries or restorations on the facial surface; } \\
\text { exclusion criteria: systematic diseases, medication affecting oral flora or salivary flow, } \\
\text { fluoride treatment in the last } 3 \text { months) }\end{array}$ & $\mathrm{CO}_{2}$ laser & 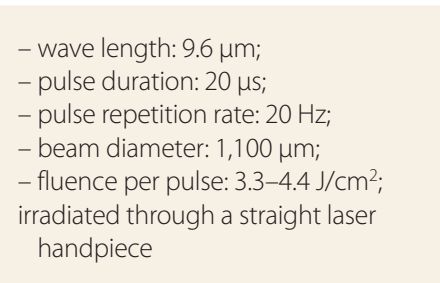 & $\begin{array}{l}\text { the laser beam was applied on enamel, } \\
\text { cervical to the bracket of the premolar on } \\
\text { one side of an imaginary line, perpendicular } \\
\text { to the brackest slot, while the other side } \\
\text { of the line in the same tooth served as } \\
\text { a controli each spot of the testing area } \\
\text { was irradiated with } 20 \text { pulses and laser } \\
\text { irradiation was applied only once }\end{array}$ & $\begin{array}{l}4 \text { weeks for one group } \\
(12 \text { patients) and } \\
12 \text { weeks for the other } \\
\text { group (12 patients); } \\
\text { then the teeth were } \\
\text { extracted }\end{array}$ & $\begin{array}{c}\text { overall relative mineral } \\
\text { loss in the 4-week and } \\
12 \text {-week arms in the } \\
\text { irradiated and control } \\
\text { enamel }\end{array}$ & $\begin{array}{l}\text { cross-sectional microhardness } \\
\text { testing }\end{array}$ \\
\hline $\begin{array}{l}\text { Suetenkov } \\
\text { et al. } \\
2015^{20}\end{array}$ & RCT & $\begin{array}{l}\text { dental caries and oral hygiene } \\
\text { in the group with traditional } \\
\text { preventive measures and the } \\
\text { group with laser therapy and } \\
\text { traditional preventive measures }\end{array}$ & $\begin{array}{l}60 \text { patients (20 girls, } 40 \text { boys), age: } 12-13 \text { years, } \\
\text { divided into } 2 \text { groups (30 patients in each group) }\end{array}$ & $\begin{array}{l}\text { Optodan } \\
\text { (low- } \\
\text { intensity) } \\
\text { laser }\end{array}$ & $\begin{array}{l}\text { - wave length: } \\
\text { - } .98-0.85 \mathrm{~nm} ; \\
\text { - power: } 0.5-1.0 \mathrm{~W} ; \\
\text { - pulse repetition rate: } 2000 \mathrm{~Hz} ; \\
\text { - time: } 2 \text { min for each segment }\end{array}$ & $\begin{array}{l}\text { the irradiated area included } 2 \text { segments } \\
\text { (upper and lower teeth aligments); } \\
\text { irradiation was applied after professional } \\
\text { oral hyggiene measures were taken, and } \\
\text { there were } 4 \text { courses per year, every } \\
3 \text { months }\end{array}$ & $\begin{array}{l}1 \text { year (after } \\
\text { orthodontic treatment } \\
\text { completion and } \\
\text { removing orthodontic } \\
\text { brackets) }\end{array}$ & $\begin{array}{l}\text { oral hygiene and caries } \\
\text { intensity before and after } \\
\text { orthodontic treatment in } \\
\text { both groups }\end{array}$ & $\begin{array}{l}\text { visual examination to } \\
\text { determine OHI-S, } \\
\text { DMFT index and DMFS index } \\
\text { before and after the treatment } \\
\text { for both groups }\end{array}$ \\
\hline
\end{tabular}

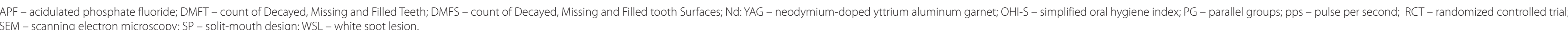


Table 3. Summary of the results of the studies included

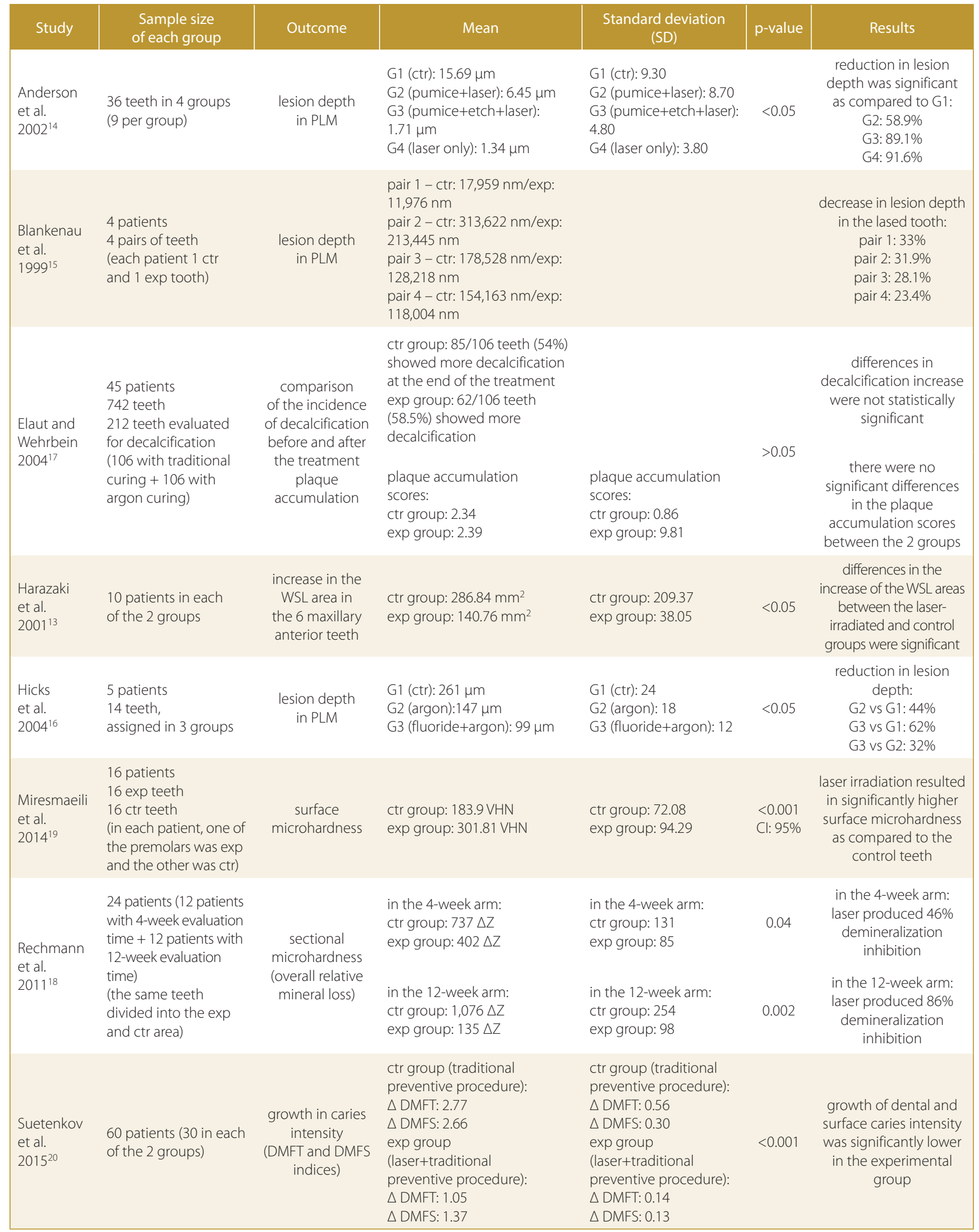

$\mathrm{Cl}$ - confidence interval; ctr - control; DMFT: count of Decayed, Missing and Filled Teeth; DMFS: count of Decayed, Missing and Filled tooth Surfaces; $\triangle \mathrm{DMFT}$ and $\triangle \mathrm{DMFS}$ - growth in caries intensity indices; exp - experimental; G - group; PLM - polarized light microscopy; VHN - Vickers hardness number (measurement unit for surface microhardness); WSL - white spot lesion; $\Delta Z$ - overall relative mineral loss (measured by plotting normalized volume percent mineral against distance from the enamel surface; vol\% $\times \mu \mathrm{m})$. 


\section{The most effective and safest laser types and parameters for the prevention of enamel demineralization}

Studies that compared the effectiveness of 2 or more laser beams in demineralization inhibition during orthodontic treatment were all in vitro. ${ }^{21,22}$ Studies that compared the effect of different parameters of the same laser type were also in vitro and did not concern orthodontic treatment. There were no studies undertaken during orthodontic treatment comparing the improvement in demineralization resistance among different laser types or different laser settings.

\section{Discussion}

The prevention of demineralization or WSL formation during orthodontic treatment is one of the most difficult challenges orthodontists have to face. Many preventive procedures have been used in the literature for this purpose. Laser irradiation has been widely studied in vitro and showed its effectiveness in increasing enamel resistance to decalcification, suggesting that it could be useful during orthodontic treatment. As presented in the literature, many laser types have been used to prevent enamel demineralization around orthodontic appliances, including Er:YAG, ${ }^{23-25} \mathrm{Nd}$ :YAG, ${ }^{13,21,22} \mathrm{CO}_{2},{ }^{18-22,26-28}$ diode, ${ }^{29,30}$ and argon laser. ${ }^{14-17,31,32}$ Although the clinical application of lasers during orthodontic treatment for a preventive purpose is still limited, the present review showed clinical effectiveness of laser irradiation in inhibiting enamel demineralization.

There were no clinical trials that applied Er:YAG or diode lasers during orthodontic treatment to prevent WSL formation.

In 3 studies, the application of argon laser irradiation on the enamel surface showed significant reduction in lesion depth in comparison with non-irradiated teeth, and its effect was significantly higher when it was combined with fluoride application, ${ }^{14-16}$ but the sample sizes in these studies were small, with short follow-up periods. The effect of irradiation with an argon laser on WSL formation while curing the adhesives of orthodontic brackets was evaluated in 1 RCT lasting 1 year, but no significant effect on enamel demineralization was observed. ${ }^{17}$

Irradiation with a $\mathrm{CO}_{2}$ laser had a significant effect on enamel microhardness around orthodontic brackets and it decreased mineral loss in comparison with non-irradiated enamel in 2 RCTs. ${ }^{18,19}$ The wave lengths applied clinically were $9.6 \mu \mathrm{m}$ and $10.6 \mu \mathrm{m}$, respectively. However, the effect of $\mathrm{CO}_{2}$ lasers during orthodontic treatment was not evaluated for a long follow-up period.

The effect of Nd:YAG laser irradiation on existing WSLs was studied in only 1 clinical trial, with a 1 -year follow-up. ${ }^{13}$ The increases in the WSL area were signifi- cantly lower in the laser-irradiated group of patients in comparison with the control group. This type of laser had not been previously applied clinically on sound enamel during orthodontic treatment to prevent decalcification.

The effect of an Optodan laser on enamel demineralization was studied in a RCT by comparing the development of tooth caries intensity (growth of the Decayed, Missing and Filled Teeth index $-\triangle \mathrm{DMFT}$, and growth of the Decayed, Missing and Filled tooth Surfaces index $-\triangle \mathrm{DMFS}$ ) between the laser group and the control group for a 1-year follow-up period, and it showed significantly lower caries intensity in the lased group as compared to the control non-irradiated group. ${ }^{20}$

Changes in the enamel structure after laser irradiation were evaluated in 2 of the included studies by scanning electron microscopy. Miresmaeili et al. evaluated enamel surface changes by extracting 2 premolars (irradiated and control) of 1 patient after 1 week of $\mathrm{CO}_{2}$ laser irradiation; the lased tooth showed melting of the enamel surface. ${ }^{19}$ As studied in the literature, the prevention of caries by $\mathrm{CO}_{2}$ laser irradiation could stem from reduced enamel permeability and solubility as a result of melting. ${ }^{33,34} \mathrm{Ha}-$ razaki et al. studied enamel changes after Nd:YAG irradiation in vitro. ${ }^{13}$ The irradiated portion of the tooth had a smooth surface with a small number of cracks.

The limitations of this review are related primarily to the lack of high-level evidence from RCTs and the heterogeneity among studies in irradiation protocols, outcomes, follow-up periods, and methods of outcome measurement.

\section{Conclusions}

This review showed that laser irradiation may be effective in preventing demineralization during orthodontic treatment, but further studies are needed, including RCTs using different lasers, to evaluate which is the most effective laser and what settings should be used. There is also a need for longer follow-up periods to evaluate the longevity of treatment.

\section{References}

1. Bergstrand F, Twetman S. A review on prevention and treatment of post-orthodontic white spot lesions - evidence-based methods and emerging technologies. Open Dent J. 2011;5:158-162.

2. Sudjalim TR, Woods MG, Manton DJ. Prevention of white spot lesions in orthodontic practice: A contemporary review. Aust Dent J. 2006;51(4):284-289, quiz 347.

3. Sundararaj D, Venkatachalapathy S, Tandon A, Pereira A. Critical evaluation of incidence and prevalence of white spot lesions during fixed orthodontic appliance treatment: A meta-analysis. J Int Soc Prev Community Dent. 2015;5(6):433-439.

4. Zabokova-Bilbilova E, Popovska L, Kapusevska B, Stefanovska E. White spot lesions: Prevention and management during the orthodontic treatment. Pril (Makedon Akad Nauk Umet Odd Med Nauki). 2014;35:161-168.

5. Lapenaite E, Lopatiene K, Ragauskaite A. Prevention and treatment of white spot lesions during and after fixed orthodontic treatment: A systematic literature review. Stomatologija. 2016;18(1):3-8. 
6. Featherstone JD. Lasers in dentistry 3. The use of lasers for the prevention of dental caries [in Dutch]. Ned Tijdschr Tandheelkd. 2002;109(5):162-167.

7. Karandish $M$. The efficiency of laser application on the enamel surface: A systematic review. J Lasers Med Sci. 2014;5(3):108-114.

8. Rodrigues LKA, de Freitas PM, Nobre-dos-Santos M. Lasers in caries prevention. In: Freitas PM, Simões A, eds. Lasers in Dentistry: Guide for Clinical Practice. Hoboken, NJ: Wiley-Blackwell; 2015:126-130.

9. Rezaei Y, Bagheri H, Esmaeilzadeh M. Effects of laser irradiation on caries prevention. J Lasers Med Sci. 2011;2(4):159-164.

10. Sadr Haghighi H, Skandarinejad M, Abdollahi AA. Laser application in prevention of demineralization in orthodontic treatment. J Lasers Med Sci. 2013;4(3):107-110.

11. Moher D, Liberati A, Tetzlaff J, Altman DG; PRISMA Group. Preferred Reporting Items for Systematic Reviews and Meta-Analyses: The PRISMA statement. Int J Surg. 2010;8(5):336-341.

12. Higgins JP, Altman DG, Gøtzsche PC, et al.; Cochrane Bias Methods Group, Cochrane Statistical Methods Group. The Cochrane Collaboration's tool for assessing risk of bias in randomised trials. BMJ. 2011;343:d5928.

13. Harazaki M, Hayakawa K, Fukui T, Isshiki Y, Powell LG. The Nd-YAG laser is useful in prevention of dental caries during orthodontic treatment. Bull Tokyo Dent Coll. 2001;42(2):79-86.

14. Anderson AM, Kao E, Gladwin M, Benli O, Ngan P. The effects of argon laser irradiation on enamel decalcification: An in vivo study. Am J Orthod Dentofacial Orthop. 2002;122(3):251-259.

15. Blankenau RJ, Powell G, Ellis RW, Westerman GH. In vivo caries-like lesion prevention with argon laser: Pilot study. J Clin Laser Med Surg. 1999;17(6):241-243.

16. Hicks J, Winn D $2^{\text {nd }}$, Flaitz C, Powell L. In vivo caries formation in enamel following argon laser irradiation and combined fluoride and argon laser treatment: A clinical pilot study. Quintessence Int. 2004;35(1):15-20.

17. Elaut $\mathrm{J}$, Wehrbein $\mathrm{H}$. The effects of argon laser curing of a resin adhesive on bracket retention and enamel decalcification: A prospective clinical trial. Eur J Orthod. 2004;26(5):553-560.

18. Rechmann $P$, Fried D, Le CQ, et al. Caries inhibition in vital teeth using 9.6- $\mu \mathrm{m} \mathrm{CO}$-laser irradiation. J Biomed Opt. 2011;16(7):071405.

19. Miresmaeili A, Farhadian N, Rezaei-soufi L, Saharkhizan M, Veisi M. Effect of carbon dioxide laser irradiation on enamel surface microhardness around orthodontic brackets. Am J Orthod Dentofacial Orthop. 2014;146(2):161-165.

20. Suetenkov DY, Petrova AP, Kharitonova TL. Photo activated disinfection efficiency of low-intensity laser and comprehensive prevention of caries and gingivitis in adolescents using bracket system. J Innovat Opt Health Sci. 2015;8(3):1541002.

21. Seino PY, Freitas PM, Marques MM, de Souza Almeida FC, Botta SB, Moreira MS. Influence of $\mathrm{CO}_{2}(10.6 \mu \mathrm{m})$ and $\mathrm{Nd}$ :YAG laser irradiation on the prevention of enamel caries around orthodontic brackets. J Lasers Med Sci. 2015;30(2):611-616.

22. Paulos RS, Seino PY, Fukushima KA, et al. Effect of $\mathrm{Nd}: Y A G$ and $\mathrm{CO}_{2}$ laser irradiation on prevention of enamel demineralization in orthodontics: In vitro study. Photomed Laser Surg. 2017;35(5):282-286.

23. Ulkur F, Sungurtekin Ekçi E, Nalbantgil D, Sandalli N. In vitro effects of two topical varnish materials and Er:YAG laser irradiation on enamel demineralization around orthodontic brackets. Sci World J. 2014;2014:490503.

24. Fornaini C, Brulat N, Milia G, Rockl A, Rocca JP. The use of sub-ablative Er:YAG laser irradiation in prevention of dental caries during orthodontic treatment. Laser Ther. 2014;23(3):173-181.

25. Garma NM, Jasim ES. The effect of Er:YAG laser on enamel resistance to caries during orthodontic treatment: An in vitro study. J Bagh Coll Dentistry. 2015;27(1):182-188.

26. de Souza-e-Silva CM, Parisotto TM, Steiner-Oliveira C, Kamiya RU, Rodrigues LK, Nobre-dos-Santos M. Carbon dioxide laser and bonding materials reduce enamel demineralization around orthodontic brackets. J Lasers Med Sci. 2013;28(1):111-118.

27. Mirhashemi AH, Hakimi S, Ahmad Akhoundi MS, Chiniforush N. Prevention of enamel adjacent to bracket demineralization following carbon dioxide laser radiation and titanium tetra fluoride solution treatment: An in vitro study. J Lasers Med Sci. 2016; 7(3):192-196.
28. Stangler LP, Romano FL, Shirozaki MU, et al. Microhardness of enamel adjacent to orthodontic brackets after $\mathrm{CO}_{2}$ laser irradiation and fluoride application. Braz Dent J. 2013;24(5):508-512.

29. Lacerda ÂS, Hanashiro FS, de Sant'Anna G, Steagall W Júnior, Barbosa P, de Souza-Zaroni WC. Effects of near infrared laser radiation associated with photoabsorbing cream in preventing white spot lesions around orthodontic brackets: An in vitro study. Photomed Laser Surg. 2014;32:686-693.

30. Lara-Carrilloa E, Doroteo-Chimalb C, Lopez-Gonzaleza S, et al. Remineralization effect of low-level laser and amorphous sodium-calcium-phosphosilicate paste in teeth with fixed orthodontic appliances. Tanta Dent J. 2016;13(1):55-62.

31. Miresmaeili A, Etrati Khosroshahi M, Motahary $P$, et al. Effect of argon laser on enamel demineralization around orthodontic brackets: An in vitro study. J Dent (Tehran). 2014;11(4):411-417.

32. Noel L, Rebellato J, Sheats RD. The effect of argon laser irradiation on demineralization resistance of human enamel adjacent to orthodontic brackets: An in vitro study. Angle Orthod. 2003;73(3):249-258.

33. Stern RH, Vahl J, Sognnaes RF. Lased enamel: Ultrastructural observations of pulsed carbon dioxide laser effects. J Dent Res. 1972;51(2):455-460.

34. Borggreven JM, van Dijk JW, Driessens FC. Effect of laser irradiation on the permeability of bovine dental enamel. Arch Oral Biol. 1980;25:831-832. 